\title{
EU Grant Employment Projects, Employment and Erzincan Case
}

\author{
Murat Çetin \\ Erzincan Binali Yıldırım University, Erzincan, Türkiye
}

\begin{abstract}
European Union Council Regulation (1085/2006 dated), the Financial Instrument for Pre-Accession (IPA) as well as the other candidate and potential candidate countries constitute the basis for Turkey. The main objective of the IPA is to assist the participating countries in confronting the problems of European integration and in carrying out the necessary reforms to comply with the Copenhagen criteria for EU membership. The Youth Employment Support Operation in Sectoral Investment Areas financed under IPA is carried out for employment, the number one priority objective of its program. PYE-II Operation implemented by İŞKUR and its overall objective is to attract and to retain more people in employment by promoting youth employment and decreasing unemployment rate of young people. Within this framework, the purpose of the Operation is to increase the employability of the young people while promoting their integration into the labour market. Within the scope of the Grant Scheme for Supporting Youth Employment in Sectoral Investment Areas (PYE II), projects for motor vehicle repair and maintenance training were carried out. In this study, the contributions and effects of these projects to employment in automotive repair sector were explained.
\end{abstract}

Keywords: EU grants, project, youth, employment

\section{Introduction}

The Council Regulation No. 1085/2006 constitutes the legal basis of Instrument for Pre-Accession Assistance (IPA) for Turkey as well as other candidate and potential candidate countries. The main objective of IPA is to help the beneficiary countries to face the challenges of European integration and to implement the reforms needed to fulfil the Copenhagen criteria for EU membership. In this respect, Human Resources Development is one of the components of IPA. The Human Resources Development Operational Programme (HRD OP) sets out the programming basis for receiving assistance from IPA funds in human resources development. The overall objective of HRD OP is "to support the transition to a knowledge-based economy capable of sustainable economic growth with more and better jobs and greater social cohesion". The HRD OP has four priority axes for adaptability by supporting employment, education, lifelong learning, and social inclusion (http://www.ikg.gov.tr, 2013).

The EU contributes to youth employment in Turkey and provides employment programs to reduce the underlying problems in the labor market. Promoting Youth Employment in Sectoral Investment Areas financed under IPA the number one priority of the operation is to contribute to employment growth and continuity of employment. The main purpose of the program is to support and recruit more people by reducing youth unemployment and to employ them. These programs, which are implemented in line with the Council

Murat Çetin, PhD, professor, Department of Mechanical Engineering, Engineering Faculty, Erzincan Binali Yıldırım University, Erzincan, Türkiye. 
Regulation of the European Framework of Cooperation, aim to contribute to the creation of more and equal opportunities for young people, to increase the employment of young people, and to facilitate cooperation between relevant national. This program also aims local actors to facilitate the transition from College to work and to reduce the main problems of the youth in the labor market in Turkey (MLSS, 2013). Turkey's demographic structure is showing some important characteristics with respect to young people. As a result of Address Based Population Registration System (ABPRS) based on t; Turkey's total population as of the end of the year $2018(82,003,882)$, has been identified as 12,971,396 young people in the 15-24 age group. According to these data, while the young population corresponds to 15.8 percent of the total population, $51.2 \%$ of this young population is young male population and $48.8 \%$ is young female population. According to the Labor Force Survey, in March 2019 unemployment rate in Turkey reached 14.1\%.The 15 and over age group at the number of unemployed compared to the same period last year, young unemployed people increased on 1.334 million and has been 4.554 million people in Turkey. While the unemployment rate in the young population (15-24 years) was $25.2 \%$ with an increase of 7.5 points, this rate was realized as $14.3 \%$ in the $15-64$ age group with an increase of 4 points. The number of employed persons decreased by 704,000 persons in March 2019 compared to the same period of the previous year and was realized as $45.4 \%$ with 2700,7950 persons and employment rate decreased by 1.7 points (TUIK, 2018).

According to the results of the labor force survey in youth, while the unemployment rate was $20.8 \%$ in 2017 , it was $20.3 \%$ in 2018 . Unemployment rate for young men decreased by 0.2 points to $17.6 \%$ compared to the previous year and for young women this rate decreased by 0.8 points compared to the previous year and became $25.3 \%$. According to the results of the household labor force survey, when the employment rate of young people is examined compared to the previous year, in 2018, the employment rate of youth increased by 0.7 points to $35 \%$. When youth employment is analyzed by gender; employment rate increased on 1 percentage point for young men to $46.4 \%$. Employment growth in young women increased on 0.4 points to $23.4 \%$. And $14.1 \%$ of working young men are employed in the agricultural sector, $36 \%$ in the industrial sector, and $49.9 \%$ in the service sector. In March 2019, the share of employees without any social security institutions increased by 1.5 points compared to the same period of the previous year and became $33.9 \%$. The share of informal workers in the non-agricultural sector increased by 1.2 points to $23.1 \%$ compared to the same period of the previous year (TUIK, 2019).

This high level of youth unemployment is associated with a number of reasons that create a barrier to youth entry to the labor market. Among the most important economic, social, and institutional reasons leading to youth unemployment is the lack of holistic employment policies and services to support youth employment. Problems encountered in the transition from College to work (lack of a structural system to help young people find jobs in the transition from College to work, lack of work experience, etc.), incompatibility between inadequate job and vocational counseling services, investment/labor demand and vocational training are important factors. Insufficient information flow between universities and industry is due to insufficient guidance and counseling mechanism to support students, university graduates, and insufficient mechanism to provide information about job opportunities. The Program for Supporting Youth Employment in Sectoral Investment Areas (PYE II) Grant Scheme aims to contribute to the creation of a more employable youth population as a result of project trainings, and to reduce youth unemployment by focusing on the above mentioned problems. In addition, in order to contribute to the incentive system made under State Support in Investments on 06.04.2012, investment areas that will benefit from regional incentives were reviewed and 
supported to be revised on sectoral and provincial basis. It is highly ensured that the project proposals, which are of great importance for this call for proposals, are compatible with the new incentive system (ISSKUR, 2016).

\section{EU Grant Projects and Sector Cooperation}

Today, as change happens very quickly, countries are struggling with education, health, and economy to raise their welfare levels. At the center of this struggle is the ideal of a highly educated society that produces development-based knowledge and technology. Universities, in addition to the education and training activities and the training of the personnel that the region needs, are also involved in the research and development activities to produce the knowledge that the region, the country, or the world will need. University for the high welfare of the society is one of the leading institutions for producing information, having information, renewing existing information, and transforming new information into new technological products. Sectoral structures diversified by their fields of study, small and medium-sized enterprises (SMEs) are of great importance in all countries, and these enterprises (SMEs) increase employment at local, regional, and national level especially in our country. Universities can contribute to the establishment of the scientific infrastructure of the sectors by producing solutions to sector problems by carrying out applied researches with organizations such as the Chamber of Commerce Industry and the Chamber of Craftsmen in their cities. As a result of the cooperation of the universities with the institutions, concrete projects related to the region have been realized and the projects that have been brought together by the potential project partners and the projects that have been accomplished are of great importance. Academic-level project outputs at universities generate social and economic value by using them on the commercial field or forming the basis of other projects. Projects made with grant schemes have features that can raise awareness as a mechanism to support regional policy instruments or existing tools. Capacity building with EU grant-backed development programs and regional projects coordinated by different ministries has strengthened the network structure to include all actors from place to place. Projects, every sector of the economy in our country provides opportunities for the rehabilitation of equipment and equipment for both Colleges and sectors while contributing to vocational training needs through the use of new technologies (Çetin \& Orman, 2009).

European union, by establishing partnerships with countries that share the same core values in democracy, human rights, and market economy, contributes financially to economic and social developments through various financial instruments. These countries are the countries in the European continent that are trying to become a member of the EU or are in the process of membership since they are accepted as candidate countries, and the countries in this process receive financial support as a pre-accession assistance. The grant schemes offer institutions the opportunity to prepare and implement projects for their own needs, while also increasing their local participation, employment, and production capacity. Institutions which receive financial support from the EU, at the same time, contributes to the design and implementation of public policies in areas other than health, education, infrastructure, and rural development. Projects supported by different sources, are policy tools that allow better identification of needs, harmonization with national priorities, developing bottom-up planning by increasing participation, promoting local partnerships and collaborations, increasing project capacity, and ensuring transparency. On the other hand, projects with its competitive nature, enhances transparency as it includes stages such as selection criteria, independent evaluation, and public announcement of winners. In addition, with its structure that requires cooperation and coordination it contributes to 
accountability by clearly demonstrating the participation and responsibilities of staff at all levels. For example, the increase in grants and project awareness in our provinces contributes to the recognition of the EU and the elimination of prejudices, while grants produce positive effects for the target audience and secondary stakeholders. Projects, while contributing to the increase of educated workforce and the development of human capital, which can use new technologies with access to modern technologies, it supports the employment increase of the sectors by creating awareness in the society in terms of the competitiveness of institutions. Education projects ensure the sustainability of employment by increasing the level of employment of individuals as a result of human capital gaining sufficient knowledge and equipment. The projects contribute to the determination of local and regional priorities, the need for resources in the region, and the applicability of the relevant plans and policies. Achieving the success and sustainability of the projects will increase the quality of the project beneficiaries and increase their entrepreneurship and competitiveness by establishing their business in business growth or in direct beneficiaries, and the commercial vitality that will occur (http://ec.europa.eu/regional policy/en/funding/ipa/, 2013).

\section{The Role of Projects in Technological Renewal and Erzincan Vocational College Example}

The strength of the countries depends on the continuity of the skills of young generations to train as creative, productive, and responsible individuals to the business world and the society of the future. Achieving this in our country is possible with the dedication of all segments of society to work together in goals and strategies. The projects play an important role in strengthening the technological infrastructures of vocational Colleges, informing the educators according to new technology, determining the local labor market needs in the provinces, raising the workforce among the registered unemployed in the fields needed by the industry and reducing unemployment. In projects aiming to equip laboratories with equipment, cooperation with industry companies and provincial dealers is important. It provides vocational education to an average of 30-40 students per year in fully equipped laboratories established with such project supports. While the College laboratories are equipped with special equipment for technological education for applied education to be carried out, educators have the opportunity to renew themselves in entrepreneurial spirit and quality systems by using high technology systems. Especially in the undeveloped province universities are the most effective and innovative institutions that will increase their potential in economic and social terms. In this context; Erzincan Vocational College, which is a model education unit for our city and region, is in communication, interaction, and cooperation with the industry sector and all segments of the society. As a result of this communication, interaction, and cooperation, education programs are updated within the framework of university-local government-industry cooperation for the qualified intermediate manpower needed considering the country. While Erzincan Vocational College meets the industrial internship, employment, and vocational training and consultancy demands of the students, seminars and conferences are organized in which the successful businessmen in our city come together with our students. On the other hand, various professional trainings for the society and the unemployed are provided by cooperating with the Chamber of Commerce, Union of Tradesmen, and NGOs and EU grants and SODES projects. Erzincan Binali Yıldırım University Vocational College between the years of 2006-2016, three EU Grant Projects were completed, and the management and training of the project was carried out as the partner of three EU Grant Projects. In addition, within the scope of Social Support Program (SODES) projects, they undertook the trainings of two vocational education projects and made one SODES project. Since 2006, Erzincan Binali Yıldırım University Vocational College has been 
actively involved in the applications of 11 projects, which have been opened under the EU Instrument for Pre-Accession Assistance (IPA), supporting lifelong learning, supporting women's employment, supporting youth employment, and supporting formal employment. As a result of these projects of vocational trainings, approximately 275 disadvantaged target groups have been trained and contributed to their employment in sectoral areas. Such project studies have improved the institutionalization and functionalities of civil organizations and have made great achievements in terms of the success of the projects, the modeling of the project activities, and the renewal of the projects in the future. Depending on the realization of these goals, institutionalization, changes in management models and innovations have increased in the auto repair shops in our city. As a result of the project activities, University-Industry Cooperation improved by mutual interaction and cooperation between the parties was increased. Erzincan Vocational College has been the driving force of this cooperation and the influence of vocational colleges on institutions in cities is high especially for cooperation of universities in undeveloped provinces. Since 2006, Erzincan Binali Yıldırım University Erzincan Vocational College has been the most effective institution providing sustainability in the development process of our city (six). Tables 1 and 2 show the distributions of EU and Social Support Program (SODES) projects, which are owned and partnered by Erzincan Vocational College.

Table 1

Projects of Erzincan Vocational College

\begin{tabular}{|c|c|c|c|c|}
\hline Years & Beneficiary & Program Title & Title Project Name & Budget (Euro) \\
\hline $2006-2007$ & $\begin{array}{l}\text { Erzincan Vocational } \\
\text { College }\end{array}$ & Local Development Initiatives & $\begin{array}{l}\text { Educated Mechanic, Clean Vehicle and } \\
\text { Clean Environment }\end{array}$ & 70,500 \\
\hline 2006-2007 & $\begin{array}{l}\text { Erzincan Vocational } \\
\text { College }\end{array}$ & Local Development Initiatives & $\begin{array}{l}\text { Computer Aided (CNC Machining } \\
\text { Systems Training) }\end{array}$ & 93,555 \\
\hline 2013-2014 & $\begin{array}{l}\text { Erzincan Vocational } \\
\text { College }\end{array}$ & $\begin{array}{l}\text { Social Support } \\
\text { Program(SODES) }\end{array}$ & $\begin{array}{l}\text { Automotive Electronics and Diagnostic } \\
\text { Education Project }\end{array}$ & 32,000 \\
\hline 2016-2017 & $\begin{array}{l}\text { Erzincan Vocational } \\
\text { College }\end{array}$ & $\begin{array}{l}\text { Supporting Young Employment } \\
\text { in Sectoral Investment Areas II }\end{array}$ & $\begin{array}{l}\text { Innovations in Auto Repairs, Young } \\
\text { Generation and New Horizons }\end{array}$ & 246,805 \\
\hline Total & & & & 442,860 \\
\hline
\end{tabular}

Table 2

Projects That Erzincan Vocational College Is a Partner

\begin{tabular}{lllll}
\hline Years & Beneficiary & Program Title & Title Project Name & Budget (Euro) \\
\hline $2010-2011$ & $\begin{array}{l}\text { Erzincan Province Special } \\
\text { Administration }\end{array}$ & $\begin{array}{l}\text { Support for Women's } \\
\text { Employment }\end{array}$ & $\begin{array}{l}\text { Let Women Hands Touch, Let the } \\
\text { Country Be Fruitful }\end{array}$ & 228,807 \\
\hline $2010-2011$ & $\begin{array}{l}\text { Erzincan Social Assistance and } \\
\text { Solidarity Foundation }\end{array}$ & $\begin{array}{l}\text { Support for Women's } \\
\text { Employment }\end{array}$ & Second Spring in Erzincan & 320,521 \\
\hline $2010-2011$ & $\begin{array}{l}\text { Erzincan Old Age Protection } \\
\text { and Development Association }\end{array}$ & $\begin{array}{l}\text { Support for Women's } \\
\text { Employment }\end{array}$ & $\begin{array}{l}\text { Home, Elderly, Patient and Child } \\
\text { Care Personnel Training }\end{array}$ & 205,575 \\
\hline $2012-2013$ & $\begin{array}{l}\text { Erzincan Chamber of Auto } \\
\text { Repairers }\end{array}$ & $\begin{array}{l}\text { Social Support Program } \\
\text { (SODES) }\end{array}$ & $\begin{array}{l}\text { Certified Auto RepairandVocational } \\
\text { Training }\end{array}$ & 40,000 \\
\hline Total & & & & 794,903 \\
\hline
\end{tabular}

It can observed that Erzincan Vocational College is trying to strengthen vocational education within the scope of European Union supports and shows importance and sensitivity in terms of qualitative and quantitative improvement of vocational education. The most noteworthy of these efforts is the university-sector cooperation, especially the joint EU grant projects. The establishment of a modern, exchangeable, and quality vocational-technical education system that will be able to respond to the demands of the labor market and 
sectors and to create an integrity between primary, secondary, and higher education associate degrees, is of great importance for the future. The cooperation between the sector and the university is evaluated and it is very important for Erzincan Binali Yıldırım University Vocational College to work in partnership with the business world of our university. These projects were carried out intensively in Erzincan Vocational College automotive technology program. Cooperation is very important in terms of sustainability of the projects and our partners are professional chambers of Erzincan Chamber of Commerce and Erzincan Union of Craftsmen and Artisans Chambers. Erzincan Vocational College continues to work with social initiatives with the formation of a trusting, encouraging, and courageous structure that will enable the public institutions, educational institutions, local governments, professional organizations, and non-governmental organizations in our province to be active in the future project activities. These projects, which were successfully completed at our College, made a big contribution to our Collegeas our technological equipment (Çetin \& Orman, 2009; Cetin, 2012). Table 3 shows the machinery, equipment, and equipment purchased by the project support for the machinery and automotive technology programs of the Erzincan Vocational College.

Table 3

Equipments Provided by Erzincan Vocational College From Projects

\begin{tabular}{|c|c|c|}
\hline Years & Project name & Receiving equipment \\
\hline $2006-2007$ & $\begin{array}{l}\text { Educated Mechanic, Clean Vehicle } \\
\text { and Clean Environment }\end{array}$ & $\begin{array}{l}1 \text { pcs Bosch FSA } 751 \text {, KTS } 650 \text { fault finding device, } 1 \text { pcs Bosch BEA } 370 \\
\text { Emissions tests device, } 1 \text { pcs gasoline engine, } 1 \text { pcs diesel engine, } 1 \text { pcs } \\
\text { carbon cleaner device, } 2 \text { pcs Tool set ( } 120 \text { pieces), } 1 \text { pcs Diesel injector } \\
\text { testing and setting device, } 1 \text { pcs photocopy machine, } 1 \text { pcs laptop computer, } \\
1 \text { pcs printer, } 1 \text { pcs desktop computer, } 2 \text { pcs projectors }\end{array}$ \\
\hline 2006-2007 & $\begin{array}{l}\text { ComputerAided (CNC Machining } \\
\text { Systems Training) }\end{array}$ & $\begin{array}{l}1 \text { pcs CNC Lathe, } 1 \text { pcs CNC Milling Machine, } 1 \text { pcs photocopy machine, } 1 \\
\text { pcs laptop computer, } 12 \text { pcs desktop computers, } 2 \text { pcs projectors }\end{array}$ \\
\hline 2013-2014 & $\begin{array}{l}\text { Automotive Electronics and } \\
\text { Diagnostic Education Project }\end{array}$ & 1 pcs photocopy machine, 1 pcs laptop computer, 1 pcs desktop computer \\
\hline 2016-2017 & $\begin{array}{l}\text { Innovations in Auto Repairs, Young } \\
\text { Generation and New Horizons }\end{array}$ & $\begin{array}{l}5 \text { pcs Tool set ( } 120 \text { pieces), } 1 \text { gas welding machine, } 1 \text { pcs battery charger, } 3 \\
\text { pcs laptop computers, } 2 \text { pcs desktop computers, } 1 \text { pcs diesel motor car } 2016 \\
\text { model (training, application and experimental research vehicle) }\end{array}$ \\
\hline
\end{tabular}

\section{Results}

Vocational technical training is an expensive education due to the requirement of various technological tools, hardware, software, laboratories, and constant renewal. The speed with which technological developments emerge is more than the speed at which educational institutions are able to understand the value of these new tools in their learning processes and to be able to make informed practices. Since technological tools and equipment are obsolete over time and technologically obsolete, continuous renewal of all equipment requires a serious resource. For technological innovations, the most important activity to be performed in the hardware update of the laboratories is to use resources from various project supports. This resource problem can be done by preparing projects that need to be done in the solution and presenting them to different units that provide project support. In addition, to improve and restructure laboratory conditions, projects should contribute to the organization of trainings to ensure that students with technical and vocational training have the qualifications and equipment to meet the industry's expectations. As a result, it is imperative that every educational unit or entire education system has a mission and vision related to educational technology. In this mission and vision, the parameters that determine the technology target should be made not on remote control solutions, but based on the targets that are aimed to be changed in the education system. The systematic 
approach to the renewal of educational technology, the need for analysis, strategy and solution suggestions should be compatible with the grant projects and project objectives, and College objectives should overlap. Care should be taken to plan community and human-centered processes that are characterized by a sustainability-based structure at all stages of decision making. Since projects that local partners do not accept and internalize and embrace cannot be successful, it is very important for local partners to have the same feelings of equivalent emotion and common sense for the success of social education projects.

\section{References}

Cetin, M. (2012). EU education project of effects on auto mechanics in terms of health, safety and environmental sensitivity. Energy Education Science and Technology Part B: Social and Educational Studies, 4(1), 87-96.

Çetin, M., \& Orman, K. (2009). Erzincan reflections of EU grant projects and looking to the future. In Proceedings of International Congress on Intercultural Dialogue and Education, Bursa.

IPA and HRD OP. (2013). Retrieved from: http://www.ikg.gov.tr

Ministry of Labour and Social Security (MLSS). (n.d.). European union coordination department.

Pre-Accession Assistance (IPA). (2013). Retrieved from: http://ec.europa.eu/regional policy/en/funding/ipa/

Promoting Registered Employment II. (n.d.). Grant scheme, guidelines for grant applicants. Ankara, Turkey.

Turkey Business Association (İŞKUR). (2016). World labor market. 8th General Assembly Working Paper, Ankara, Turkey.

Turkey Statistical Agency (TUIK). (2018a). Newsletter. Ankara, Turkey.

Turkey Statistical Agency (TUIK). (2018b). Provincial population report. Ankara, Turkey. 